\title{
Genotoxic and Cytotoxic Safety Evaluation of Papain (Carica papaya L.) Using In Vitro Assays
}

\author{
Claudia R. da Silva, ${ }^{1,2,3,4}$ Marcia B. N. Oliveira, ${ }^{1,2}$ Ellen S. Motta, ${ }^{2}$ \\ Gabriella S. de Almeida, ${ }^{1,3}$ Leandro L. Varanda, ${ }^{1,3}$ Marcelo de Pádula, ${ }^{3,4}$ \\ Alvaro C. Leitão, ${ }^{3}$ and Adriano Caldeira-de-Araújoo ${ }^{1,2}$ \\ ${ }^{1}$ Laboratório de Análise de Toxicidade em Fitoterápicos, Departamento de Biofísica e Biometria, Instituto de Biologia Roberto \\ Alcantara Gomes, UERJ, 20551-030 Rio de Janeiro, RJ, Brazil \\ ${ }^{2}$ Laboratório de Radio e Fotobiologia, Departamento de Biofísica e Biometria, Instituto de Biologia Roberto Alcantara Gomes, \\ UERJ, 20551-030 Rio de Janeiro, RJ, Brazil \\ ${ }^{3}$ Laboratório de Radiobiologia Molecular, Instituto de Biofísica Carlos Chagas Filho, UFRJ, 21941-902 Rio de Janeiro, RJ, Brazil \\ ${ }^{4}$ Laboratório de Diagnóstico Molecular e Hematologia, Departamento de Análises Clínicas e Toxicológicas, \\ Faculdade de Farmácia, UFRJ, 21941-902 Rio de Janeiro, RJ, Brazil
}

Correspondence should be addressed to Claudia R. da Silva, crsilva@uerj.br

Received 23 November 2009; Revised 16 March 2010; Accepted 16 March 2010

Academic Editor: Michael Cunningham

Copyright (C) 2010 Claudia R. da Silva et al. This is an open access article distributed under the Creative Commons Attribution License, which permits unrestricted use, distribution, and reproduction in any medium, provided the original work is properly cited.

Papain, a phytotherapeutic agent, has been used in the treatment of eschars and as a debriding chemical agent to remove damaged or necrotic tissue of pressure ulcers and gangrene. Its benefits in these treatments are deemed effective, since more than 5000 patients, at the public university hospital at Rio de Janeiro, Brazil, have undergone papain treatment and presented satisfactory results. Despite its extensive use, there is little information about toxic and mutagenic properties of papain. This work evaluated the toxic and mutagenic potential of papain and its potential antioxidant activity against induced- $\mathrm{H}_{2} \mathrm{O}_{2}$ oxidative stress in Escherichia coli strains. Cytotoxicity assay, Growth inhibition test, WP2-Mutoxitest and Plasmid-DNA treatment, and agarose gel electrophoresis were used to investigate if papain would present any toxic or mutagenic potential as well as if papain would display antioxidant properties. Papain exhibited negative results for all tests. This agent presented an activity protecting cells against $\mathrm{H}_{2} \mathrm{O}_{2}-$ induced mutagenesis.

\section{Introduction}

The belief that natural medicines are much safer than synthetic drugs has caused exceptional growth in human exposure to natural products, as plants, phytotherapeutic agents, and phytopharmaceutical products. This fact has lead to a resurgence of scientific interest in their biological effects. In most countries there is no universal regulatory system insuring the safety and activity of natural products and they had not been sufficiently investigated analytically or toxicologically [1].

Herbal medicines can be potentially toxic to human health. In this way, scientific research has shown that many plants used in traditional and folk medicine are potentially toxic, mutagenic, and carcinogenic [1-9].
Carica papaya L. (C. papaya L.) is the most important species within the Caricaceae genus, being widely cultivated for consumption as a fresh fruit, as juices, and as dried and crystallized fruit. Papaya also has several industrial uses [10-12]. Biochemically, its leaves and fruits are complex, representing sources of several proteins and alkaloids with important pharmaceutical, medical, and industrial applications. The juice is used for curing warts, cancer, and tumors. Leaves have been poultice into nervous pain. The hypoglycemic effect has been reported. It is used to treatment of infected wounds, malignant tumors, and burns [10].

The juice of ripe papaya displayed in vivo and in vitro activities against oxidative stress $[13,14]$. It is an efficient scavenger of highly reactive hydroxyl radicals $\left(\mathrm{OH}^{*}\right)$ formed during ${ }^{60}$ Co irradiation [13]. 
The green (unripe) papaya, which is rich in papain, is used for dressing of ulcers. This treatment is described as effective and it is recommended in preference to other dressings for chronic skin ulcers. It has been used in many countries such as England, Nigeria, Ghana, Gambia, India, and Jamaica [15]. In spite of its extensive use, the following disadvantages were described, as problems concerning the availability of green papaya and difficulties in preparing and storing papaya [15].

The demonstration of the phytotherapeutic potential of a given species is a difficult task, since plant extracts consist of complex mixtures of major compounds, minor concomitant agents, and fibers, which can all be involved in the observed effects. Thus, given the difficulties in determining the contribution of a specific substance in the biological effects exerted by whole extracts, the aim of this work was the study of papain isolated from C. papaya, which possesses vast application in medicine.

Papain, a purified protein extracted from the latex of the unripe papaya, is widely used by Brazilian nurses in traditional medicine. It can be an alternative to green papaya and it can be used as phytotherapeutic agent in the treatment of pressure ulcers, gangrene, eschars, and as a debriding chemical agent to remove damaged or necrotic tissue [16]. Papain is sometimes used in association with hydrous magnesium silicate (talc). Its benefits in these treatments are deemed effective, since more than 5000 patients at the Pedro Ernesto University Hospital, at Rio de Janeiro/Brazil, have undergone papain treatment and presented satisfactory results [16]. Despite its extensive use, there is little information about toxic, mutagenic, and antioxidant properties of papain itself or even unripe papaya, which contains high concentration of papain [12].

Short-term tests have been used to check compounds for their ability to induce lesions in DNA, which may lead to genotoxicity, cytotoxicity, or mutagenicity. The experimental techniques using microbial cells such as Escherichia coli (E. coli) and Salmonella typhimurium (S. typhimurium), as well as assays using DNA as the target molecule, allowed the development of new tools to investigate toxic and mutagenic potentials of many physical and chemical agents and their correlation with the effects in eukaryotic systems $[1,17-20]$.

Hydrogen peroxide $\left(\mathrm{H}_{2} \mathrm{O}_{2}\right)$ is a normal cell metabolite formed in several enzymatic and nonenzymatic reactions. $\mathrm{H}_{2} \mathrm{O}_{2}$ leads to oxidative stress, mutagenicity, loss of cell function, and ultimately apoptosis or necrosis [18, 21, 22]. In E. coli, a major component of the $\mathrm{H}_{2} \mathrm{O}_{2}$ toxicity is attributed to DNA damage mediated by the Fenton reaction, which generates reactive oxygen species (ROSs), such as $\mathrm{OH}^{\bullet}[21-$ 27]. E. coli possesses a number of antioxidant enzymes and DNA repair activities encoded by several genes $(x t h \mathrm{~A}, m u t \mathrm{Y}$, $o x y \mathrm{R}$, among others) to counteract DNA damage caused by oxidative stress. Mutant strains lacking one or more of those genes are usually hypersensitive to $\mathrm{H}_{2} \mathrm{O}_{2}[18,21,22,26]$. So, Blanco and coworkers (1998) designed a series of E. coli WP2 tester strains (IC203 up to IC207, used in this study), which are useful for the screening of mutations resulting from oxidative stress as well in studies on antioxidants [18].
It is well documented that oxidative damage has been implicated in various systemic chronic diseases such as cancer, Alzheimer's disease, rheumatoid arthritis, cardiovascular disease, cataracts, and other ageing processes. Reactive oxygen species (ROSs) are essential intermediates in oxidative metabolism. Nonetheless, when generated in excess, ROSs in various active forms can damage tissues [28].

In recent years, there has been a considerable interest in finding natural antioxidants from plant materials to replace synthetic molecules. Data from both scientific reports and laboratory studies show that plants contain a large variety of substances that possess antioxidant activity. Phytochemicals with antioxidant effects include some cinnamic acids, coumarins, diterpenes, flavonoids, lignans, monoterpenes, phenylpropanoids, tannins, and triterpenes. Natural antioxidants occur in all higher plants and in all parts of the plant (wood, bark, stems, pods, leaves, fruit, roots, flowers, pollen, and seeds) $[29,30]$.

The present work was carried out to evaluate the potential cytotoxic and mutagenic effects of papain using E. coli strains and plasmid DNA. In addition, we have also investigated papain antioxidant and antimutagenic activities against oxidative stress induced by $\mathrm{H}_{2} \mathrm{O}_{2}$.

\section{Experimental Procedures}

2.1. Bacterial Strains and Plasmid. E. coli strains AB1157 (wild type); BH20 (fpg); PQ65 (rfa); BW9091 (xthA); DH5 $\alpha$ F'IQ (pUC 9.1), WP2 (wild type); IC203 (uvrA oxyR pKM101), IC204 (uvrA del[umuDC]), IC205 (uvrA $\operatorname{del}[u m u \mathrm{DC}] m u t \mathrm{M}), \mathrm{IC} 206(u v r \mathrm{~A} \operatorname{del}[u m u \mathrm{DC}] m u t \mathrm{Y})$, and IC207(uvrA $\operatorname{del}[u m u \mathrm{DC}] m u t \mathrm{M}$ oxy $\mathrm{R})$ were used in this work [18, 29-34].

In order to prepare cultures to evaluate cytotoxic, antioxidant, mutagenic effects of papain and to perform reverse mutation test, the strains were grown according to previously described methods $[8,18]$.

Samples $\left(\sim 10^{7}\right.$ cells $)$ of the E. coli strain stocks were taken from frozen vials $(50 \% \mathrm{v} / \mathrm{v}$ glycerol) and grown in liquid $(10 \mathrm{~mL}) \mathrm{LB}$ medium at $37^{\circ} \mathrm{C}$, overnight with shaking (Reciprocal Water Bath Shaker, model R76, New Brunswick, Science Co. Inc, N.J. EUA) up to the stationary growth phase. From the overnight culture, a sample containing $100 \mu \mathrm{L}$ was added to $10 \mathrm{~mL}$ of fresh $\mathrm{LB}$ medium and incubated at $37^{\circ} \mathrm{C}$ for $2 \mathrm{~h}$, with shaking, to reach exponential growth phase (1-2 $\times 10^{8}$ cells $/ \mathrm{mL}$ ). Then, cells were collected by centrifugation $(7,200 \times \mathrm{g}$ in Sorvall SS-34 Rotor), washed twice with $0.9 \%$ $\mathrm{NaCl}$ sterile solution, and resuspended in the same solution for each indicated treatment [8].

Plasmid pUC 9.1 has been prepared according to a previously described alkaline method [35].

2.2. Reagents, Phytotherapeutic and Chemical Agents. Bacto agar, bacto tryptone, and bacto yeast extract were purchased from Difco Laboratories, Detroit, USA. Nutrient broth was purchased from Oxoid do Brasil, Ltda (Brazil). Papain powder (from C. papaya L., 30,000 USP-U/mg stabilized with sodium disulfite), sodium chloride, perhidrol $\left(30 \% \mathrm{H}_{2} \mathrm{O}_{2}\right)$, glucose, and tryptophan (Trp) were from Merck (Brazil); 
streptomycin, chloramphenicol, and ampicillin were from Sigma (St. Louis, USA). Ultra pure water was obtained from a Milli-Q water system from Millipore Corp, Bedford, MA, USA.

Papain powder, protected against ambient light, was suspended in $0.9 \% \mathrm{NaCl}$ sterile solution, vigorously shaken for 2 minutes at room temperature and immediately filtered through a sterile $0.22 \mu \mathrm{m}$ Millipore cellulose acetate membrane to eliminate microbial contaminants. This solution was associated or not with sterile talc (obtained after autoclavation, $121^{\circ} \mathrm{C}, 30$ minutes). This association (talc and papain) was prepared before each experiment.

For the tests, the concentration of papain was calculated based on the amount administered to the patients. The highest concentration of papain $(500 \mu \mathrm{g} / \mathrm{mL})$ to which the bacterial cultures were exposed is much greater than that used in the wounds of patients during treatment.

2.3. Culture Media, Solutions, and Cell Growth. The culture media, solutions, and cell growth were prepared as previously described $[8,17,18,35]$.

Dilutions of the chemical preparations and bacterial cultures were carried out with $0.9 \% \mathrm{NaCl}$ sterile solution, dimethyl sulfoxide (DMSO), or ultra pure Milli-Q water $[8,17,18]$.

2.4. Cytotoxicity Assay. In order to evaluate the potential cytotoxic effect of papain, culture aliquots $(1 \mathrm{~mL})$ of $E$. coli AB1157, PQ65, BH20, and BW9091 strains, in the exponential growth phase, were incubated under shaking for 60 minutes at $37^{\circ} \mathrm{C}$ with different papain concentrations $(0$, 50,250 , and $500 \mu \mathrm{g} / \mathrm{mL} 0.9 \% \mathrm{NaCl}$ sterile solution).

In order to evaluate the cytotoxic effect of papain associated with talc, aliquots $(1 \mathrm{~mL})$ of E. coli AB1157 and BW9091 strains in exponential growth phase were incubated with papain in combination with talc $(500 \mu \mathrm{g} / \mathrm{mL})$ or talc alone $(500 \mu \mathrm{g} / \mathrm{mL})$. A sample was incubated in $0.9 \% \mathrm{NaCl}$ sterile solution, under the same conditions, as a negative control. After the treatments, aliquots $(100 \mu \mathrm{L})$ were taken, diluted with $0.9 \% \mathrm{NaCl}$ sterile solution, and spread, in duplicates, on LB-plates, following incubation at $37^{\circ} \mathrm{C}$ for 24 hours. The colony-forming units were then scored and surviving fractions $\left(\mathrm{SF}=N_{60} / N_{0}\right)$ were expressed as the mean of three experiments [8].

2.5. Growth Inhibition Test. In the growth inhibition test, $100 \mu \mathrm{L}\left(\sim 10^{8}\right.$ cells) of a fresh overnight $E$. coli culture (in LB medium) were added to $3 \mathrm{~mL}$ of molten top agar and poured onto LB plates supplemented with chloramphenicol $(20 \mu \mathrm{g} / \mathrm{mL})$ or ampicillin $(20 \mu \mathrm{g} / \mathrm{mL})$, according to the tester strain. Paper discs (5 mm diameter) were impregnated with $10 \mu \mathrm{L}$ of $0.9 \% \mathrm{NaCl}$ sterile solutions containing one of the following amounts of papain $(5 ; 12.5 ; 25 ; 50 ; 100 ; 125$; 250 and $500 \mu \mathrm{g} /$ paper disc), papain (100 or $500 \mu \mathrm{g} /$ paper disc) associated with $\mathrm{H}_{2} \mathrm{O}_{2}\left(300 \mu \mathrm{g} /\right.$ paper disc) or only $\mathrm{H}_{2} \mathrm{O}_{2}$ (300 $\mu \mathrm{g} /$ paper disc) as a positive control. The impregnated paper discs were placed on the center of plates and all plates were incubated overnight at $37^{\circ} \mathrm{C}$. Inhibition halos were measured (in $\mathrm{mm}$ ) and expressed after calculating the difference between the inhibition zone diameter and the disc diameter [36].

2.6. Reverse Mutation Test in E. coli Strains (Mutoxitest). The assays were performed according to Blanco et al. (1988); E. coli IC203 and IC204 strains (both $\operatorname{Trp}^{-}$) were grown in nutrient broth liquid medium for $\sim 16$ hours at $37^{\circ} \mathrm{C}$ in agitation. A suspension of the overnight-cultured strains $(100 \mu \mathrm{L})$ was transferred to sterile screw-top tubes with $2.5 \mathrm{~mL}$ of $0.6 \%$ soft-agar at $45^{\circ} \mathrm{C}$ and various concentrations of papain $(0,12.5,25,50,125,250$, and $500 \mu \mathrm{g} /$ plate $)$ dissolved in $0.9 \% \mathrm{NaCl}$ sterile solution. The total tube content was spread immediately onto plates containing minimal ET4 agar supplemented with tryptophan $(0.01 \mathrm{mg} / \mathrm{plate})$ and incubated for 48 hours at $37^{\circ} \mathrm{C}$. The number of $\operatorname{Trp}^{+}$ revertant colonies was determined and the reversion rate was compared to control (negative and positive) plates. In these experiments, each sample was assayed using duplicate plates and the data presented was the mean of three experiments. The results were expressed as the mean \pm standard deviations (SDs). A sample was considered mutagenic when number of revertants were higher than 2 for at least one of the tested concentrations [17].

2.7. Plasmid DNA Treatment and Agarose Gel Electrophoresis. Agarose gel electrophoresis $(0.8 \%)$ was performed in order to separate different structural conformations of pUC 9.1 plasmid DNA after papain treatment: form I supercoiled (SC) native conformation, form II open circle (OC) resulting from single strand breaks, and form III linear (L) resulting from double strand breaks. Plasmid DNA aliquots (200 ng) were treated with increasing concentrations of papain for 40 minutes at $25^{\circ} \mathrm{C}$ and negative control was performed using ultra pure $\mathrm{H}_{2} \mathrm{O}$ (Milli-Q). After treatments, each sample was mixed with loading buffer $(0.25 \%$ xylene cyanol FF; $0.25 \%$ bromofenol blue; $30 \%$ glycerol in water) and submitted to agarose gel electrophoresis in Tris acetate-EDTA buffer, $\mathrm{pH} 8.0$ at $6 \mathrm{~V} / \mathrm{cm}$. After electrophoresis, the gel was stained with ethidium bromide $(0.5 \mu \mathrm{g} / \mathrm{mL})$ and the DNA bands were visualized by fluorescence in an ultraviolet DNA transiluminator system $[6,35]$. The assay was repeated, at least three times, and the bands quantified with the Gel Pro Analyzer 3.0 software (Media Cybernetics, Silver Spring, MD, USA).

2.8. Statistical Analysis of Results. The results were analyzed by ANOVA since (i) the data were normally distributed as verified by the method Kolmogorov and Smirnov and (ii) samples from populations had identical standard deviations (SDs), as verified by the Bartlett method. ANOVA was followed by the Student Newman Keuls multiple comparison test using the statistical program InStat version 3.01 (GraphPad Software, San Diego, CA, USA). These analyses compared the results obtained by the several treatments, at different papain concentrations, including the controls. A significance level of $5 \%$ was adopted to evaluate the data. 
TABLE 1

(a) Effect of different papain concentrations on the survival of E. coli strains. Exponentially growing cultures were centrifuged, washed with $0.9 \% \mathrm{NaCl}$ sterile solution, and suspended in the same solution. Aliquots $(1 \mathrm{~mL})$ of these suspensions were incubated with different papain concentrations or $0.9 \% \mathrm{NaCl}$ for 60 minutes, at $37^{\circ} \mathrm{C}$, with shaking. Afterwards, aliquots $(100 \mu \mathrm{L})$ were taken, diluted and plated onto LB medium for determining surviving fractions (SF $\left.=N_{60} / N_{0}\right)$ for each strain at different papain concentrations. Values are the mean of 3 independent experiments (6 determinations) with standard deviations not exceeding $15 \%$ (mean $\pm \mathrm{SD}$ ). $5 \%$ Significance level was adopted to compare data.

\begin{tabular}{lcccc}
\hline & \multicolumn{3}{c}{ E. colistrains $\left(\mathrm{SF}=N_{60} / N_{0}\right)$} \\
\hline Papain concentrations $(\mu \mathrm{g} / \mathrm{mL})$ & $\mathrm{AB} 1157(\mathrm{WT})$ & BW9091 $(x$ thA $)$ & BH20 $(f p g)$ & $1.10 \pm 0.05$ \\
\hline 50 & $0.81 \pm 0.04$ & $1.00 \pm 0.06$ & $0.98 \pm 0.04$ \\
250 & $1.24 \pm 0.08$ & $1.40 \pm 0.04$ & 0.02 & $1.04 \pm 0.01$ \\
500 & $0.80 \pm 0.06$ & $1.10 \pm 0.03$ & $0.90 \pm 0.04$ & $0.93 \pm 0.02$ \\
\hline Negative control $0.9 \% \mathrm{NaCl}(50 \mu \mathrm{L})$ & $1.00 \pm 0.02$ & $1.00 \pm 0.05$ & $0.90 \pm 0.03$ & $1.10 \pm 0.04$ \\
\hline Positive control $\mathrm{H}_{2} \mathrm{O}_{2}(10 \mathrm{mM})$ & $0.20^{*} \pm 0.01$ & $0.003^{*} \pm 0.00004$ & $0.17^{*} \pm 0.007$ & $0.19^{*} \pm 0.01$ \\
\hline
\end{tabular}

The results are not significantly different $(p>0.05)$ when compared to negative control.

*The results are significantly different $(p<0.05)$ when compared to negative control.

(b) Effect of papain associated with talc on the survival of E. coli strains. Exponentially growing cultures were centrifuged, washed with $0.9 \% \mathrm{NaCl}$, and suspended in the same solution. Aliquots $(1 \mathrm{~mL})$ of these suspensions were incubated with different papain concentrations (associated or not with talc) or $0.9 \% \mathrm{NaCl}$ for 60 minutes, at $37^{\circ} \mathrm{C}$, with shaking. Afterwards, aliquots $(100 \mu \mathrm{L})$ were taken, diluted and plated onto $\mathrm{LB}$ medium for determining surviving fractions ( $\mathrm{SF}=N_{60} / N_{0}$ ) for each strain. Values are the mean of 3 independent experiments (6 determinations) with standard deviations not exceeding $15 \%$ (mean $\pm \mathrm{SD}$ ). $5 \%$ significance level was adopted to compare data.

\begin{tabular}{lcr}
\hline & & E. coli strains $\left(\mathrm{SF}=N_{60} / N_{0}\right)$ \\
Agents & AB1157 (WT) & BW9091 $(x t h A)$ \\
\hline $0.9 \% \mathrm{NaCl}($ negative control) & $1.00 \pm 0.02$ & $1.00 \pm 0.04$ \\
Papain $(500 \mu \mathrm{g} / \mathrm{mL})$ & $1.00 \pm 0.03$ & $0.93 \pm 0.03$ \\
Papain associated with talc $(500 \mu \mathrm{g} / \mathrm{mL})$ & $0.80 \pm 0.01$ & $0.96 \pm 0.03$ \\
Talc $(500 \mu \mathrm{g} / \mathrm{mL})$ & $0.90 \pm 0.01$ & $0.87 \pm 0.02$ \\
$\mathrm{H}_{2} \mathrm{O}_{2}(10 \mathrm{Mm})$ (positive control) & $0.20^{*} \pm 0.004$ & $0.003^{*} \pm 0.00004$ \\
\hline
\end{tabular}

The results are not significantly different $(p>0.05)$ when compared to negative control.

*The results are significantly different $(p<0.05)$ when compared to negative control.

The data collected by densitometry provided us with null events percentage (no breaks $=p(0 ; \mu)$ ) for each one of different papain concentrations tested. Thus, the mean values of breaks per genome for each one of the concentrations using Poisson distribution were obtained as follows: $\mu=$ $-\ln p(0 ; \mu)[6]$.

\section{Results}

3.1. Cytotoxicity Assay. In order to evaluate toxic effects of papain cytotoxicity assay was performed. The results indicated that papain was not cytotoxic to E. coli strains AB1157 (wild type), PQ65 (rfa), BH20 (fpg), and BW9091 $(x t h \mathrm{~A})$ at the tested concentrations (Table 1(a)). Statistical analysis indicated that there was no significant difference $(p>0.05)$ among treated and untreated cells.

This same methodoly was used to test papain in association with talc, as shown in Table 1(b), and it was not cytotoxic, either in the wild-type or in the repair mutant $(x t h \mathrm{~A})$ strain.

Since some reports [16] preconize papain use in association with talc, we also decided to address if talc would alter cell viability. The results (Table 1(b)) showed that sterile talc was inert; therefore the subsequent tests were performed with purified papain $[10,15]$.

3.2. Growth Inhibition Test. Another methodology to investigate the toxic effect of papain comprised the use of Growth inhibition test. The results concerning papain potential toxic effects obtained with E. coli IC203, IC204, IC205, IC206, and IC207 strains revealed no formation of inhibition halos at all tested concentrations. In fact, halos were produced only with the positive control $\mathrm{H}_{2} \mathrm{O}_{2}(300 \mu \mathrm{g} /$ disc $)(p<0.001)$ when compared to negative control $(0.9 \% \mathrm{NaCl})$, as shown in Table 2.

3.3. Reverse Mutation Test in E. coli Strains (Mutoxitest). The results obtained with WP2 Mutoxitest showed that all the tested papain concentrations did not present mutagenic activity with E. coli IC203 (WP2 uvrA oxyR pKM101) and IC204 (WP2 uvrA del umuDC). There was no significant difference $(p>0.05)$ when papain treatment was compared to negative control $(0.9 \% \mathrm{NaCl})$ (Table 3$)$.

3.4. Plasmid DNA Treatment and Agarose Gel Electrophoresis. Conformational changes in plasmid DNA (pUC 9.1) after 


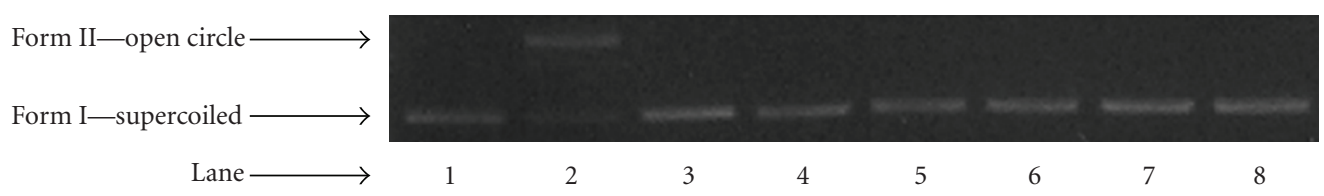

(a)

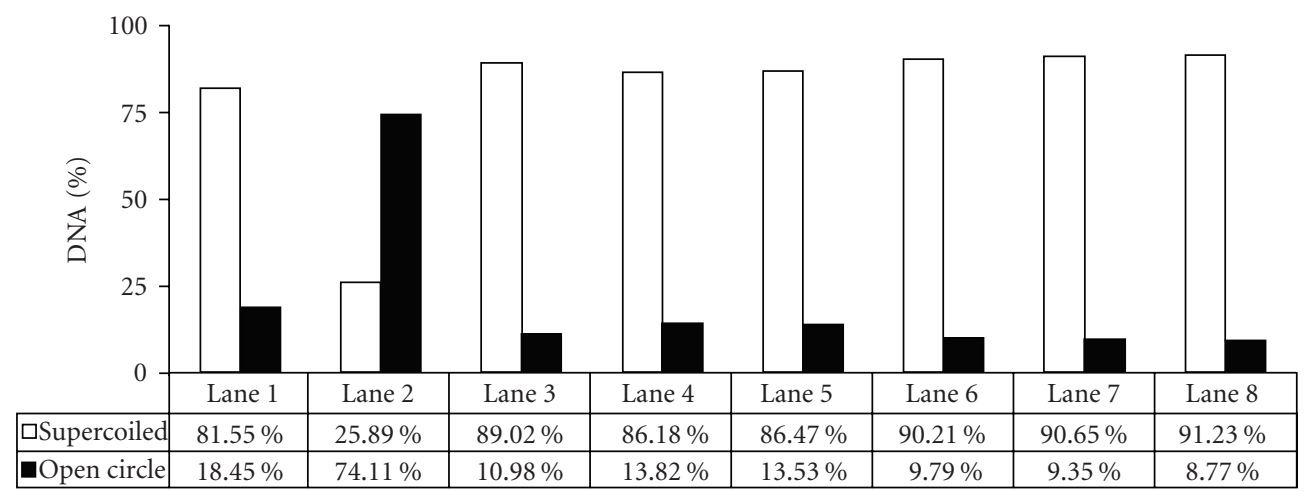

(b)

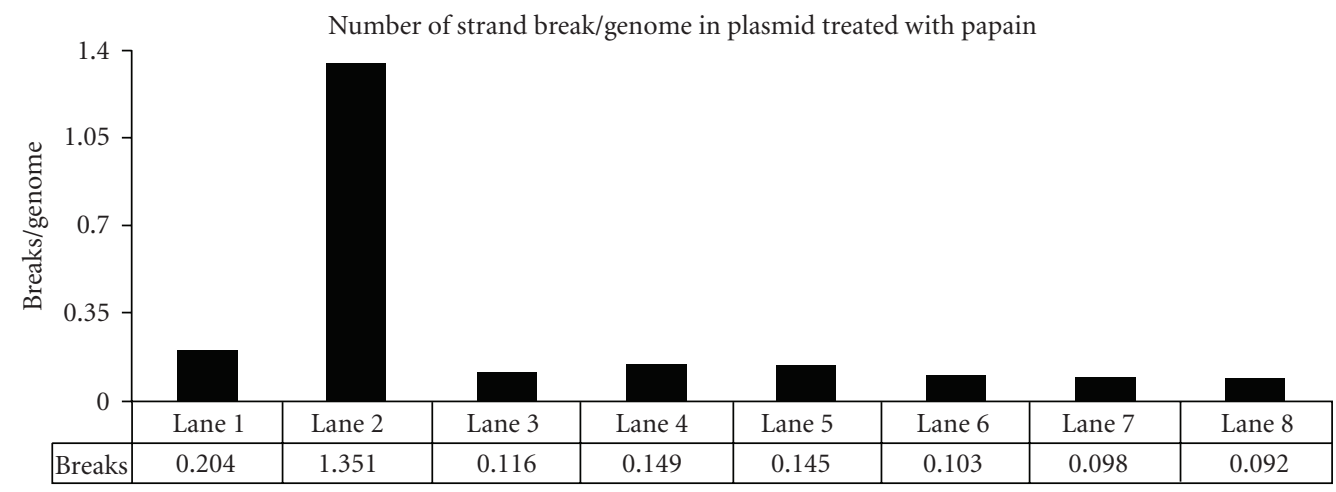

(c)

FIGURe 1: Analysis of plasmid pUC 9.1 DNA strand breaks after treatment with papain. Aliquots of pUC 9.1 plasmid DNA (200 ng) were incubated with different concentrations of papain for 40 minutes at $25^{\circ} \mathrm{C}$. Each sample was mixed with loading buffer and submitted to $0.8 \%$ agarose gel electrophoresis. The assay was repeated, at least three times. Densitometric measures were obtained from gel through Gel Pro Analyzer 3.0 software. Lanes: (1) negative control (Milli-Q water); (2) positive control $\left(\mathrm{H}_{2} \mathrm{O}_{2} 10 \mathrm{mM}\right)$; (3) $10 \mu \mathrm{g}$; (4) 25 $\mu \mathrm{g}$; (5) 50 $\mu \mathrm{g}$; (6) $100 \mu \mathrm{g}$; (7) $250 \mu \mathrm{g}$; (8) $500 \mu \mathrm{g}$ of papain.

TABLE 2: Inhibition halos ( $\mathrm{mm}$ ) of the E. coli strains after treatment with different papain concentrations mixed with hydrogen peroxide. Aliquots $(100 \mu \mathrm{L})$ of exponentially growing cultures of $E$. coli were mixed with $3 \mathrm{~mL}$ top agar $\left(44-46^{\circ} \mathrm{C}\right)$ and spread on $\mathrm{LB}$ plates supplemented with antibiotic (ampicillin or chloramphenicol, according to the strain resistance). After 15 minutes, paper discs (5 mm diameter) containing different amounts of the papain ( 100 or $500 \mu \mathrm{g} / \mathrm{disc})$ mixed or not with $\mathrm{H}_{2} \mathrm{O}_{2}(300 \mu \mathrm{g} /$ disc $)$ were placed in the center of the plates. After 24 -hour incubation at $37^{\circ} \mathrm{C}$ the inhibition halos around the disc were measured. Values are the mean of 3 independent experiments with standard deviations not exceeding $15 \%$ (mean \pm SD). $5 \%$ significance level was adopted to compare data.

\begin{tabular}{|c|c|c|c|c|c|c|}
\hline \multirow{3}{*}{ Agents $(10 \mu \mathrm{L} /$ disc $)$} & \multicolumn{6}{|c|}{ Growth inhibition halos $(\mathrm{mm})$ of E. coli strains } \\
\hline & IC203 & IC204 & IC205 & IC206 & IC207 & WP2 (WT) \\
\hline & uvrA $\operatorname{oxy} \mathrm{R}$ & uvrA umuDC & $\begin{array}{c}u v r \mathrm{~A} u m u \mathrm{DC} \\
\text { mut } \mathrm{M}\end{array}$ & $\begin{array}{c}\text { uvrA umuDC } \\
\text { mut } \mathrm{Y}\end{array}$ & $\begin{array}{c}u v r \mathrm{~A} u m u \mathrm{DC} \\
m u t \mathrm{M} \text { oxy }\end{array}$ & WPZ (W 1$)$ \\
\hline $\mathrm{H}_{2} \mathrm{O}_{2}(300 \mu \mathrm{g})$ & $48.0 \pm 1.4$ & $30.5 \pm 2.7$ & $20.0 \pm 2.4$ & $17.0 \pm 2.3$ & $37.7 \pm 1.0$ & $16.0 \pm 0.5$ \\
\hline Papain $(100 \mu \mathrm{g})$ plus $\mathrm{H}_{2} \mathrm{O}_{2}(300 \mu \mathrm{g})$ & $45.0 \pm 0.1^{*}$ & $22.0 \pm 1.8^{*}$ & $21.5 \pm 1.8$ & $16.5 \pm 1.7$ & $33.5 \pm 1.0^{* *}$ & $15.6 \pm 0.4$ \\
\hline Papain $(500 \mu \mathrm{g})$ plus $\mathrm{H}_{2} \mathrm{O}_{2}(300 \mu \mathrm{g})$ & $40.5 \pm 0.9^{*}$ & $22.0 \pm 1.9^{*}$ & $20.0 \pm 2.2$ & $17.5 \pm 2.0$ & $35.5 \pm 0.5^{* *}$ & $15.4 \pm 0.8$ \\
\hline $0.9 \% \mathrm{NaCl}$ (negative control) & ND & ND & ND & ND & ND & ND \\
\hline
\end{tabular}

ND: not detected.

${ }^{*} p<0.001$ when compared to $\mathrm{H}_{2} \mathrm{O}_{2}(300 \mu \mathrm{g} /$ disc $)$.

** $p<0.01$ when compared to $\mathrm{H}_{2} \mathrm{O}_{2}(300 \mu \mathrm{g} /$ disc $)$. 
TABLE 3: Mutoxitest-Number of $\operatorname{Trp}^{+}$revertants/plate (mean \pm SD). Aliquots $(100 \mu \mathrm{L})$ of exponentially growing cultures were mixed with $100 \mu \mathrm{L}$ of different concentrations of the papain or $0.9 \% \mathrm{NaCl}$, as negative control, and mixed with $2.5 \mathrm{~mL}$ molten top agar at $45^{\circ} \mathrm{C}$ and plated on minimal glucose agar plates supplemented with $0.5 \mathrm{mg}$ tryptophan/litre. The mutagenic responses were expressed as the absolute number of $\operatorname{Trp}^{+}$revertants/plate, after incubation at $37^{\circ} \mathrm{C}$, for 48 hours. Values are the mean of 3 independent experiments with standard deviations not exceeding $15 \%$.

Number of $\operatorname{Trp}^{+}$revertants/plate (mean $\pm \mathrm{SD}$ )

Agent ( $\mu$ g/plate) E. coli IC203 uvrA oxy $\mathrm{R}$ E. coli IC204 uvrA umuDC

Papain 5

$158 \pm 26.0$

$15 \pm 3.0$

Papain 25

$162 \pm 16.0$

$17 \pm 3.0$

Papain 50

$154 \pm 26.0$

$12 \pm 3.0$

Papain 100

$129 \pm 24.0$

$14 \pm 3.0$

Papain 125

$178 \pm 10.0$

$16 \pm 3.0$

Papain 250

$162 \pm 25.0$

$17 \pm 3.0$

Papain 500

$149 \pm 24.0$

$18 \pm 3.0$

Positive control $\mathrm{H}_{2} \mathrm{O}_{2}(300)$

$853 * \pm 70.2$

$15^{\mathrm{a}} \pm 1.9$

Negative control $0.9 \% \mathrm{NaCl}(50 \mu \mathrm{L} /$ plate $)$

$141 \pm 28.0$

$16 \pm 4.0$

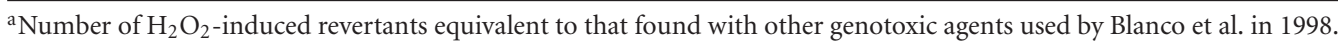

${ }^{*} p<0.001$ when compared to negative control $(0.9 \% \mathrm{NaCl})$.

treatment with different concentrations of papain were also investigated, using agarose gel electrophoresis analysis. Data showed (Figure 1) that papain treatment did not modify original plasmid DNA conformational structure (supercoiled form I).

\section{Discussion}

In patients from a Brazilian university public hospital (Pedro Ernesto Hospital), papain, associated or not with talc, is used for the topical treatment of chronic skin ulcer. It is described as effective and recommended in preference to other dressings for the same purpose, as unripe papaya, in other countries [15]. Physicians from this Hospital described the following advantages of using the papain in comparison with green papaya: dislodging of wounds, promotion of granulation tissue and healing, cost-effectiveness, standardized procedure, facility in its availability, preparing, and application [36].

Despite its extensive use in Brazilian patients, there is still little information about papain toxicity. Then, as part of a continuous effort to understand papain effects, the aim of this work was to extend knowledge concerning papain toxicity mechanisms in bacterial systems and DNA plasmid. Although usually recommended, exogenous metabolic activation system (S9 mix) was not included in the tests, since papain treatment is only used topically, on chronic skin ulcer, and is not intended for internal use.

The phytotherapeutic agent papain was not able to induce inactivation of all the $E$. coli strains tested.

Even E. coli PQ35 was as resistant as the wild type strain (Table 1(a)). E. coli PQ65 is constitutively more permeable to bulky molecules than the others E. coli strains used in this work, due to one mutation ( $r f a)$ that causes partial loss of the lipopolysaccharide barrier that coats the surface of the bacteria [33]. Therefore, two hypotheses are possible: (i) papain cannot penetrate the cell wall and exert its toxic effect even in PQ65 strain or (ii) it can penetrate the cell wall, but it is not toxic.

DNA repair deficient strains were also resistant to papain treatment (Table 1(a)). Therefore, if papain induces DNA damage, such as 8-oxoguanine, formamidopyrimidine (Fapy), or even AP sites, they may not be produced at levels high enough to cause cell lethality. Besides, one should not discard other backup DNA repair/tolerance systems that could take these lesions in charge, such as nucleotide excision repair (NER) and recombination [37].

The antioxidant activity of papain against $\mathrm{H}_{2} \mathrm{O}_{2}$-induced damage was also assessed using Growth inhibition test. When the cells were simultaneously treated with $\mathrm{H}_{2} \mathrm{O}_{2}$ $(300 \mu \mathrm{g} / \mathrm{disc})$ and papain (100 or $500 \mu \mathrm{g} / \mathrm{disc})$, there was observed a significant decrease in the growth-inhibition halo of E. coli IC203 (WP2 uvrA oxyR pKM101) ( $p<0.001$ ), IC204 (WP2 uvrA del umuDC) $(p<0.01)$, and IC207 (WP2 uvrA del umuDC mutM oxyR) $(p<0.001)$ strains, compared with the results obtained with $\mathrm{H}_{2} \mathrm{O}_{2}$ treatment alone. Alternatively, there was no significative decrease $(p>$ 0.05 ) in the growth-inhibition halos with the other studied strains, IC205 (uvrA umuDC mutM) and IC206 (uvrA umuDC mut $\mathrm{Y}$ ) (Table 2). It is important to note that the increase of papain to $500 \mu \mathrm{g} /$ disc was able to produce further protection to IC203 (WP2 uvrA oxyR pKM101), but not to all other strains. This indicates that papain excess may prevent the production of DNA lesions majorly repaired by nucleotide excision repair $(u v r \mathrm{~A})$ and by the oxy $\mathrm{R}$ tolerance system. In fact, when base excision repair (mut $\mathrm{M}$ and/or $m u t Y$ ) or UmuD and UmuC proteins are absent, the excess of papain is unable to produce further cell protection.

Mutoxitest is a potent assay to assess the ability of a series of compounds to induce reversion of the trpE65 mutation in E. coli from auxotrophy to prototrophy [18] and is currently accepted as a validated short-term genotoxicity 
test by international regulatory agencies [38]. The results obtained with E. coli IC203, IC204, and IC207 strains treated in presence of $\mathrm{H}_{2} \mathrm{O}_{2}$ can be interpreted as indicative of an antioxidant property of papain. In this way, it can protect against genotoxic and/or mutagenic effects of $\mathrm{H}_{2} \mathrm{O}_{2}$, when OxyR regulon and/or NER system are absent. On the other hand, papain did not protect strains IC205 and IC206 from the $\mathrm{H}_{2} \mathrm{O}_{2}$ deleterious effects. These results, at first sight, seem to contrast with those about the antioxidant potential of papain. However, they may also indicate that papain could not prevent the generation of certain premutagenic $\mathrm{H}_{2} \mathrm{O}_{2}$-induced lesions in DNA, such as 8-oxoguanine. It was already observed that strains deficient in MutM or MutY DNA glicosilases are highly susceptible to SOS-independent mutations promoted by these lesions [17]. In fact, papain could be efficient in scavenging only certain specific ROS generated by $\mathrm{H}_{2} \mathrm{O}_{2}$ treatment, eliminating hydroxyl and/or superoxide radicals, but not singlet oxygen, the major species responsible for the formation of 8-oxoguanine lesions in DNA $[22,39,40]$.

Circular plasmid DNA was used in vitro as target to study the induction of strand breaks in DNA by compounds such as oxidant agents and natural products $[6,8,41,42]$. Papain did not induce single or double strand breaks in DNA in vitro. In the context of the methodology used in this work, these results reinforce the idea that the papain is neither a cytoxicity nor genotoxic agent.

Our study indicates that papain is not toxic and/or mutagenic in bacterial systems. Indeed, papain revealed to be an antioxidant agent against $\mathrm{H}_{2} \mathrm{O}_{2}$-induced damage.

Webman and coworkers (1989) and Mehdipour and coworkers (2006) demonstrated an antioxidant effect of ripe C. papaya $\mathrm{L}$ juice, which is poor in papain content. In this case, the antioxidant properties found in papaya juice cannot be unequivocally attributed to papain and may be due to other antioxidant substances. In fact, only unripe fruit contains papain [12].

A problematic aspect in understanding potential toxicological events relevant to the medicinal use of $C$. papaya $\mathrm{L}$. and many other medicinal plants is that the exact amounts of active chemicals are unknown.

Oloyede (2005) studied unripe pulp of C. papaya and its chemical compositon was determined [11]. In general, the results from this phytochemical screening suggest the validity of therapeutical effect of aqueous extract of unripe pulp of C. papaya. But studies on the toxicity of these compounds, separately, were not performed.

Our results further support the notion that papain, the compound isolated from latex of unripe C. papaya $\mathrm{L}$, is a promising source of potential antioxidant. A more detailed investigation of papain for the antioxidant activity is in progress using lower eukaryotic organisms, as yeast $S$. cerevisiae.

\section{Acknowledgments}

The authors gratefully acknowledge the following institutions and members of (1) FVIB-Instituto de Investigaciones Citológicas, Valencia/Spain, Dr. M. Blanco who kindly sup- plied them with E. coli WP2 tester strains; (2) IBRAG/UERJ, Brazil: Elizangela F. da Silva, Herika M. da Rocha, Paulo Thiago S. Santos, Monica Ribeiro Monteiro, Simone Simplício, Andreia F. Ribeiro, Dr. Michelle P. Rodrigues, Dr. Roberto Bezerra, and Antonio P. das Neves (in memorian) for their technical assistance; (3) HUPE/UERJ, Brazil: Marise Oliveira, Anderson Loureiro, Vânia Coutinho, and Dr. Luciana Assad for their technical assistance and kindly supplied them with papain and talc; and (4) UFRJ, Brazil: Janine S. C. Rurr and Rita de Cássia Albuquerque for their technical assistance. This work was supported by the CNPq, CAPES, UERJ/SR-2, the Comissão de Curativos/HUPE/UERJ, UERJ/PGBN, and FAPERJ.

\section{References}

[1] L. G. Valerio Jr. and G. F. Gonzales, "Toxicological aspects of the South American herbs cat's claw (Uncaria tomentosa) and maca (Lepidium meyenii): a critical synopsis," Toxicological Reviews, vol. 24, no. 1, pp. 11-35, 2005.

[2] U. Mengs, "Toxic effects of sennosides in laboratory animals and in vitro," Pharmacology, vol. 36, no. 1, pp. 180-187, 1988.

[3] A. C. Leitão and R. S. Braga, "Mutagenic and genotoxic effects of mate (Ilex paraguariensis) in prokaryotic organisms," Brazilian Journal of Medical and Biological Research, vol. 27, no. 7, pp. 1517-1525, 1994.

[4] C. A. S. Fonseca, S. S. Otto, F. J. R. Paumgartten, and A. C. Leitão, "Nontoxic, mutagenic, and clastogenic activities of mate-chimarrao (Ilex paraguariensis)," Journal of Environmental Pathology, Toxicology and Oncology, vol. 19, no. 4, pp. 333$346,2000$.

[5] S. C. Matthews, A. Camacho, K. Lawson, and J. E. Dimsdale, "Use of herbal medications among 200 psychiatric outpatients: prevalence, patterns of use, and potential dangers," General Hospital Psychiatry, vol. 25, no. 1, pp. 24-26, 2003.

[6] S. C. Ferreira-Machado, M. P. Rodrigues, A. P. M. Nunes, et al., "Genotoxic potentiality of aqueous extract prepared from Chrysobalanus icaco L. leaves," Toxicology Letters, vol. 151, no. 3, pp. 481-487, 2004.

[7] M. Déciga-Campos, I. Rivero-Cruz, M. Arriaga-Alba, et al., "Acute toxicity and mutagenic activity of Mexican plants used in traditional medicine," The Journal of Ethnopharmacology, vol. 110, no. 2, pp. 334-342, 2007.

[8] C. R. Silva, M. R. Monteiro, H. M. Rocha, et al., "Assessment of antimutagenic and genotoxic potential of senna (Cassia angustifolia Vahl.) aqueous extract using in vitro assays," Toxicology in Vitro, vol. 22, no. 1, pp. 212-218, 2008.

[9] R. Teschke, A. Genthner, and A. Wolff, "Kava hepatotoxicity: comparison of aqueous, ethanolic, acetonic kava extracts and kava-herbs mixtures," Journal of Ethnopharmacology, vol. 123, no. 3, pp. 378-384, 2009.

[10] I. F. Starley, P. Mohammed, G. Schneider, and S. W. Bickler, "The treatment of paediatric burns using topical papaya," Burns, vol. 25, no. 7, pp. 636-639, 1999.

[11] O. I. Oloyede, "Chemical profile of unripe pulp of Carica papaya," Pakistan Journal of Nutrition, vol. 4, no. 6, pp. 379381, 2005.

[12] A. El Moussaoui, M. Nijs, C. Paul, et al., "Revisiting the enzymes stored in the laticifers of Carica papaya in the context of their possible participation in the plant defence mechanism," Cellular and Molecular Life Sciences, vol. 58, no. 4, pp. 556-570, 2001. 
[13] E. J. Webman, G. Edlin, and H. F. Mower, "Free radical scavenging activity of papaya juice," International Journal of Radiation Biology, vol. 55, no. 3, pp. 347-351, 1989.

[14] S. Mehdipour, N. Yasa, G. Dehghan, et al., "Antioxidant potentials of Iranian Carica papaya juice in vitro and in vivo are comparable to $\alpha$-tocopherol," Phytotherapy Research, vol. 20, no. 7, pp. 591-594, 2006.

[15] H. Hewitt, S. Whittle, S. Lopez, E. Bailey, and S. Weaver, "Topical use of papaya in chronic skin ulcer therapy in Jamaica," West Indian Medical Journal, vol. 49, no. 1, pp. 3233, 2000.

[16] C. E. Almeida, C. C. Nascimento, E. S. Brandão, et al., Manual para Realização de Curativos, Cultura Médica,, Rio de Janeiro, Brasil, 2002.

[17] D. M. Maron and B. N. Ames, "Revised methods for the Salmonella mutagenicity test," Mutation Research, vol. 113, no. 3-4, pp. 173-215, 1983.

[18] M. Blanco, A. Urios, and A. Martinez, "New Escherichia coli WP2 tester strains highly sensitive to reversion by oxidative mutagens," Mutation Research, vol. 413, no. 2, pp. 95-101, 1998.

[19] H. S. Rosenkranz, "A paradigm for determining the relevance of short-term assays: application to oxidative mutagenesis," Mutation Research, vol. 508, no. 1-2, pp. 21-27, 2002.

[20] R. C. Horn and V. M. Ferrão Vargas, "Antimutagenic activity of extracts of natural substances in the salmonella/microsome assay," Mutagenesis, vol. 18, no. 2, pp. 113-118, 2003.

[21] J. A. Imlay and S. Linn, "DNA damage and oxygen radical toxicity," Science, vol. 240, no. 4857, pp. 1302-1309, 1988.

[22] J. A. Imlay, "Pathways of oxidative damage," Annual Review of Microbiology, vol. 57, pp. 395-418, 2003.

[23] J. M. Mates, C. Perez-Gomez, and I. N. Nunez de Castro, "Antioxidant enzymes and human diseases," Clinical Biochemistry, vol. 32, no. 8, pp. 595-603, 1999.

[24] S. Bjelland and E. Seeberg, "Mutagenicity, toxicity and repair of DNA base damage induced by oxidation," Mutation Research, vol. 531, no. 1-2, pp. 37-80, 2003.

[25] M. S. Cooke, M. D. Evans, M. Dizdaroglu, and J. Lunec, "Oxidative DNA damage: mechanisms, mutation, and disease," Journal of the Federation of American Societies for Experimental Biology, vol. 17, no. 10, pp. 1195-1214, 2003.

[26] N. R. Asad, L. M. B. O. Asad, C. E. B. de Almeida, I. Felzenszwalb, J. B. Cabral-Neto, and A. C. Leitão, "Several pathways of hydrogen peroxide action that damage the E. coli genome," Genetics and Molecular Biology, vol. 27, no. 2, pp. 291-303, 2004.

[27] J. Emerit, M. Edeas, and F. Bricaire, "Neurodegenerative diseases and oxidative stress," Biomedicine \& Pharmacotherapy, vol. 58, no. 1, pp. 39-46, 2004.

[28] Q. Shi and G. E. Gibson, "Oxidative stress and transcriptional regulation in Alzheimer disease," Alzheimer Disease and Associated Disorders, vol. 21, no. 4, pp. 276-291, 2007.

[29] A. Chanwitheesuk, A. Teerawutgulrag, and N. Rakariyatham, "Screening of antioxidant activity and antioxidant compounds of some edible plants of Thailand," Food Chemistry, vol. 92, no. 3, pp. 491-497, 2005.

[30] P. Howard-Flanders and L. Theriot, "Mutants of Escherichia coli K12 defective in DNA repair and genetic recombination," Genetics, vol. 53, pp. 1137-1150, 1966.

[31] B. Demple, J. Halbrook, and S. Linn, "Escherichia coli xth mutants are hypersensitive to hydrogen peroxide," Journal of Bacteriology, vol. 153, no. 2, pp. 1079-1082, 1983.
[32] D. Hanahan, "Studies on transformation of Escherichia coli with plasmids," Journal of Molecular Biology, vol. 166, no. 4, pp. 557-580, 1983.

[33] P. Quillardet and M. Hofnung, "The SOS Chromotest, a colorimetric bacterial assay for genotoxins: procedures," Mutation Research, vol. 147, no. 3, pp. 65-78, 1985.

[34] S. Boiteux and O. Huisman, "Isolation of a formamidopyrimidine-DNA glycosylase $(f p g)$ mutant of Escherichia coli K12," Molecular \& General Genetics, vol. 215, no. 2, pp. 300-305, 1989.

[35] J. Sambrook, E. F. Fritisch, and T. Maniatis, "Extraction and purification of plasmid DNA," in Molecular Cloning: A Laboratory Manual, book 3, Cold Spring Harbor Laboratory, New York, NY, USA, 2nd edition, 1989.

[36] C. Alfaro, A. Urios, M. C. Gonzalez, P. Moya, and M. Blanco, "Screening for metabolites from Penicillium novae-zeelandiae displaying radical-scavenging activity and oxidative mutagenicity: isolation of gentisyl alcohol," Mutation Research, vol. 539, no. 1-2, pp. 187-194, 2003.

[37] E. Friedberg, G. C. Walker, W. Siede, R. D. Wood, R. A. Schultz, and T. Ellenberger, DNA Repair and Mutagenesis, American Society for Microbiology, Washington, DC, USA, 2006.

[38] K. Mortelmans and E. S. Riccio, "The bacterial tryptophan reverse mutation assay with Escherichia coli WP2," Mutation Research, vol. 455, no. 1-2, pp. 61-69, 2000.

[39] I. Schulz, H.-C. Mahler, S. Boiteux, and B. Epe, "Oxidative DNA base damage induced by singlet oxygen and photosensitization: recognition by repair endonucleases and mutagenicity," Mutation Research, vol. 461, no. 2, pp. 145-156, 2000.

[40] S. S. Wallace, "Biological consequences of free radicaldamaged DNA bases," Free Radical Biology and Medicine, vol. 33, no. 1, pp. 1-14, 2002.

[41] I. W. Reiniger, C. Ribeiro da Silva, I. Felzenszwalb, et al., "Boldine action against the stannous chloride effect," Journal of Ethnopharmacology, vol. 68, no. 1-3, pp. 345-348, 1999.

[42] A. A. Paes-Leme, E. S. Motta, J. C. P. de Mattos, F. J .S. Dantas, R. J. A. C. Bezerra, and A. Caldeira-de-Araujo, "Assessment of Aloe vera (L.) genotoxic potential on Escherichia coli and plasmid DNA," Journal of Ethnopharmacology, vol. 102, no. 2, pp. 197-201, 2005. 

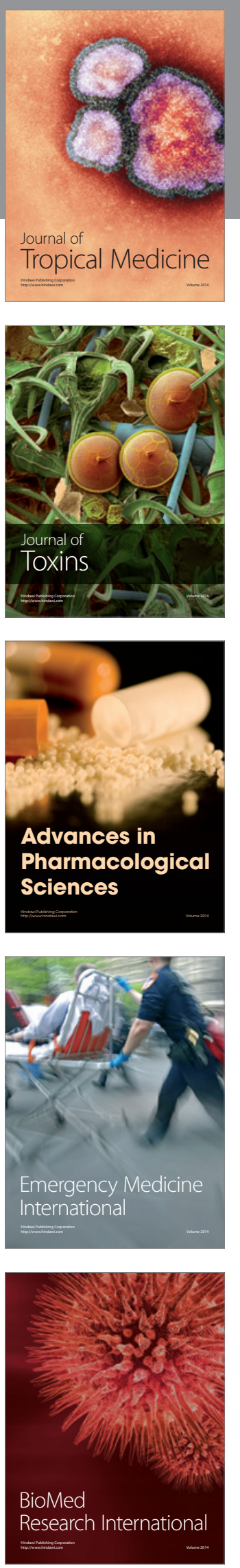
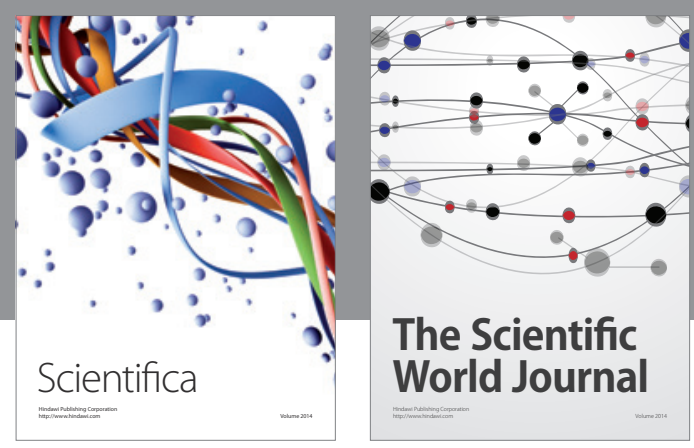

The Scientific World Journal
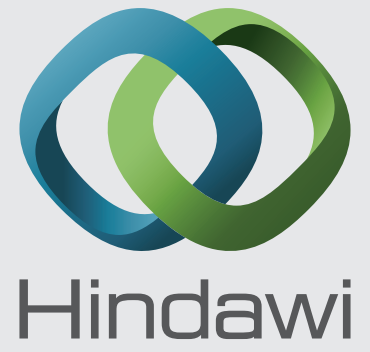

Submit your manuscripts at

http://www.hindawi.com
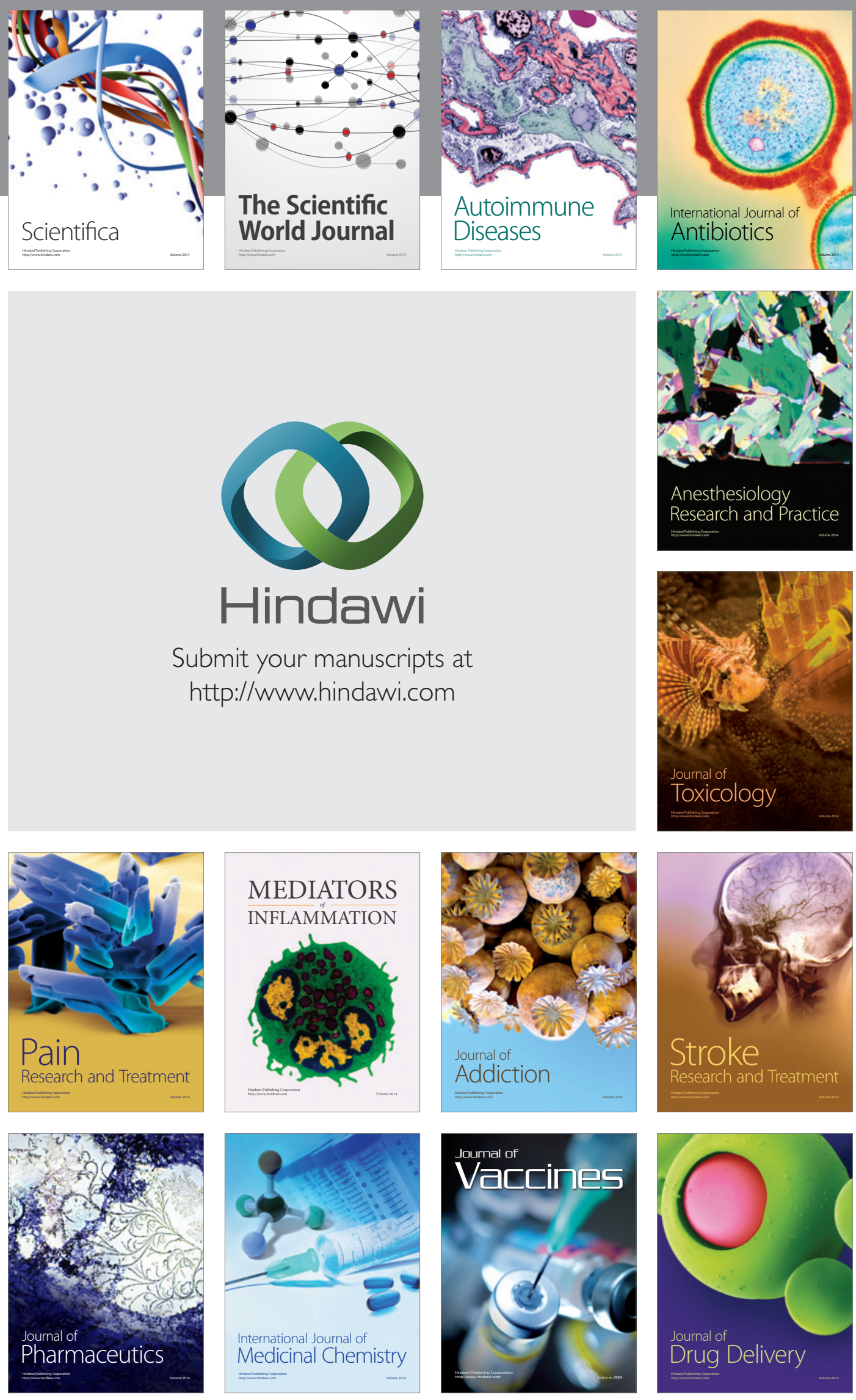